\title{
Acceptance of E-Learning among Undergraduates of Computing Degrees in Sri Lanka
}

\author{
Dushyanthi U. Vidanagama \\ Kotelawala Defence University, Rathmalana, 10390, Sri Lanka \\ Email: udeshika@kdu.ac.lk
}

\begin{abstract}
E-learning has become a most popular learning approach of higher education in Sri Lanka, due to the advancements of Information Technology. This study focused on the undergraduates' acceptance of elearning as an effective tool. The successfulness of implementing e-learning requires the understanding of end-user acceptance process. Therefore, this study focused on investigating the acceptance of e-learning approach among undergraduates in Western Province, Sri Lanka. The aim of this research was to provide a set of factors to be considered when an E-learning activity is planned and proposed to E-learners in universities of Sri Lanka. The Technology Acceptance Model which was modified by including some factors was used as the basic framework of this study which was suitable for achieving the objectives of the research. This study was based on total sample of 209 students who are following Computing degrees in the universities located in Western Province, Sri Lanka. The results of this study suggested that university students tend to focus more on perceived ease of use on e-learning and the students' attitude has more influence on intention to use e - learning. So it could be concluded that providing more technological facilities with infrastructure would increase the positive attitude towards using e-learning among university students and behavioral intention to use.
\end{abstract}

Index Terms-E-learning, Technology Acceptance Model, Perceived ease of use, Perceived usefulness, Perceived enjoyment.

\section{INTRODUCTION}

The rapid advancements of information technology create opportunities and innovations within the learning environment of the Sri Lankan universities. E-Learning provides a Web-based learning platform with realistic and more flexible framework which would be able to support for both teacher and learner [1].E-learning allows the knowledge to be shared among a wide audience through the tools and systems such as Internet, Intranet, email, chat, discussion groups, wikis, blogs etc. E-learning provides various services which are customized according to the students' needs, knowledge, expertise and experience [2].In Sri Lankan context e-learning is enrolled into the university education system to increase the access to higher education and to improve the quality of learning in universities[2]. E-learning can be treated as a facilitator for the teaching-learning process.

E-learning provides several advantages to the university students over the traditional learning systems. The traditional learning system is bounded by the place, time and people while the e-learning has no limitations of learning. It is an unbounded learning system which can be used at anytime and anywhere.

As e-learning is a technology related system, the developers and the deliverers need to have the understanding of how the users perceive and react to the e-learning systems. That will create a better understanding of how to design and deliver the e-learning approach to the users effectively and efficiently in order to increase the learning experience.

Although many universities in Sri Lanka have incorporated on developing e-learning systems within the university by their own, the success of the system would be depended on the acceptance of the university students who are involving it. Adoption to technology could be studied at two levels either through organization and individual [3]. The focus of this study was at the individual level, so the emphasis went to the university students who were currently using e-learning system incorporated with their day to day learning process. In order to accomplish this, the research model of this study was based on Technology Acceptance Model (TAM) [8], [5], the most commonly used model to explain the technology acceptance behavior among users [6].

It is founded that TAM has been used to explain the theoretical model in many studies which were based on users' perceived acceptance of any technology. This study considered TAM as the base model with some integrated factors to investigate the attitude towards using e-learning and the behavior of intention to use it. The main focus of this research was to answer the following research questions: (1) What are the main factors that are effecting the university students' perceived usefulness, perceived ease of use, and perceived enjoyment over the usage of e-learning? (2) What are the factors that are effecting the university students' attitude towards using elearning and intention to use it? (3) The strength of the significant factors of the research model. 
The objective of this study was to analyse the elearning acceptance behavior of the Sri Lankan university students that would provide better understandings of implications to successfully implement e-learning systems in Sri Lankan universities. This study focused on only the students who were involving in computing degrees in Sri Lankan university system.

The second section of this paper includes the background and motivation to this study. The third section summarizes the developed research model and the hypotheses which were going to test. The forth section discusses the research methodology while the fifth section gives the full details about the data analysis and results. The last three sections includes the implications and recommendations to the followers, limitations of this research, future directions and the final conclusion.

\section{LITERATURE REVIEW}

TAM is an information systems theory which describes how the users accept and react while using a technology. According to this model, the number of factors may influence the decision of users on how the users intention to use it. This model was created based on the Theory of Reasoned Action (TRA) [8], [9] in psychology research. TRA suggests that a person's behavior when using a technology is determined by his/her intention to perform the behavior and the perceived behavioral control [10]. The intention is determined by three things, their attitude toward the specific behavior, their subjective norms and their perceived behavioral control [10]. It stated that one's behavior and the intention to behave is a function of one's attitude toward the behavior and the perceptions about the behavior [11].TRA is presented in Fig.1.

According to TAM, the acceptability of technology is determined by two main factors: perceived usefulness and perceived ease of use (Fig.2).Perceived usefulness is the degree to which a person believes that working with such a technology will improve his job performance. Perceived ease of use refers to the degree to which a person believes that using such a technology will be effortless and easy to use. Several factorial analyses demonstrated that perceived usefulness and perceived ease of use can be considered as two different dimensions of human beings [13], [14].

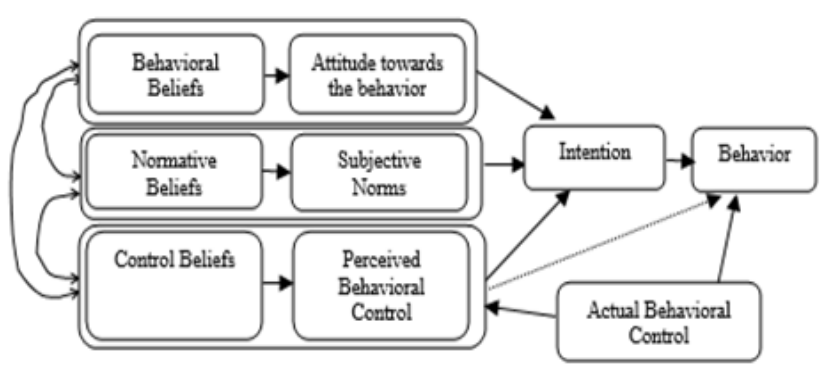

Fig.1. Theory of Reasoned Action (TRA)

Usage behavior of any technology is determined by the behavioral intention. The behavioral intention is determined by the person's attitude towards the use of the system and also by his perception of its utility. Therefore, even if a user does not accept a technology, the probability that he will use it is high if he perceives that the system will improve his performance at work. Also the TAM shows a direct link between perceived usefulness and perceived ease of use.

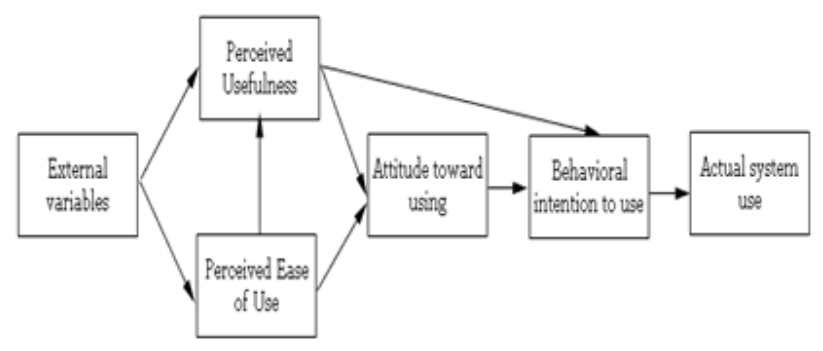

Fig.2. Technology Acceptance Model

It shows that if there are two systems with same features, but the users have to select only one option, then the user finds more useful the one that he finds easier to use [15]. Fig.2 represents the original version of TAM [8].

Several researches had identified the important factors for the acceptance of e-learning by using the TAM. Ref. [21] examined the effects of perceived interaction, perceived infrastructure and perceived usefulness (PU) on satisfaction (CS), and the effects of them on online learning continuance intention (e-loyalty). The study showed a significant amount of variance in online learning satisfaction and e-loyalty. The satisfaction and perceived usefulness were identified as two significant drivers of behavioral intention towards continuous use of online learning course, Also perceived usefulness had a direct effect on behavioral intention. Further it revealed that, confirmation, compatibility, service instruction, instructor interaction, information, and enjoyment explained a significant variance in satisfaction.

Ref. [22] indicated that instructor characteristics and teaching materials are the predictors of the perceived usefulness of e-learning, and perceived usefulness and playfulness are the predictors of the intention to use elearning. perceived ease of use was shown to have the weakest effect on the intention to use e-learning among the perceived usefulness, perceived ease of use and playfulness. Poor internet services, software and infrastructure could affect the students' willingness to accept e-learning [23]. Therefore, a user-friendly system is important especially to assist students who have problems in using some of the e-learning tools. Moreover, students thought that the infrastructure of the technology and e-learning system should be upgraded.

Ref. [3] found that perceived ease of use and perceived usefulness have a positive effect on the behavioral intention of students to use e-learning. Also it showed that the quality of the systems has a positive relationship with behavioral intention of students. There is a positive relationship of attitude with behavioral intention towards learning through e-learning systems. The computer selfefficacy also has a positive relationship with the behavioral intention of students. So these studies revealed 
that it has become essential for academic institutions to identify the factors affecting students intention towards adoption of learning through e-learning.

Ref. [24] believed that a combination of both models could provide important insights into the -learning technologies. It showed that there is a positive relationship between the Perceived Ease of Use of an elearning factors that potentially influence students' attitude toward using e technology and the attitude toward using it, its Perceived Usefulness, and its perceived enjoyment. Also there is a positive relationship between the Instructor's Attitude towards E-Learning Technologies and the Learner's perceived usefulness of these technologies. Also there is a positive relationship between the Instructor's Computer Competence and the learner's perceived ease of use of e-learning technologies. There is a positive relationship between the presence of games within e-learning technologies and the learner's perceived enjoyment of these technologies. Also there is a positive relationship between Working in Groups with e-learning technologies and the learner's perceived enjoyment/perceived ease of use of these technologies. There is a positive relationship between the availability of required IT-Infrastructure for e-learning technologies and the learner's perceived enjoyment /perceived ease of use of these technologies.

\section{RESEARCH MODEL AND HYPOTHESES}

According to the TAM, the modified research model which was used for this research is presented in Fig.3.

Perceived usefulness is the degree to which a person believes that using a particular system would enhance his/her job performance [4]. The model suggested that usage of E-learning has a positive effect on the performance of the student. Perceived ease of use is the degree to which a person believes that using a particular system would be free of effort and easy[8]. So the model suggested that the students who use E-learning were expected to be comfortable with the learning efforts they make. Perceived enjoyment is the degree to which a person believes that using a particular system would be enjoyable. The model suggested that the presence of entertainment of E-learning materials would make the students more enjoyable with the learning effort.

Task-technology fit has a positive impact on individual performance and be used if the availability of the technology matches the tasks that the user must perform [19]. Experience is the number of years the students are involved with E-learning. The model suggests that the experience would make E-learning useful and easy to use. Computer competence is the knowledge of using computer and internet. It is the self- confidence and the ability to perform tasks across multiple application domains [20]. IT infrastructure is the availability of necessary equipment and facilities to work with Elearning.

Support is the help gaining from the supporting staff of the university in the process of E-learning. The Elearning materials can be made more entertained if they are presented with audio, video, multimedia etc. Attitude towards E-learning can be defined as the reaction and communication toward the E-learning efforts.

In order to accomplish the previously stated objectives, this study tested the following hypotheses:

$\mathbf{H}_{\mathbf{1}}$ :University students' perceived usefulness of Elearning is effected by task-technology fit $\left(\mathrm{H}_{11}\right)$,experience $\left(\mathrm{H}_{12}\right)$ and perceived ease of use ELearning $\left(\mathrm{H}_{13}\right)$

$\mathbf{H}_{2}$ : University students' perceived ease of use Elearning is effected by computer competence $\left(\mathrm{H}_{21}\right)$, IT infrastructure $\left(\mathrm{H}_{22}\right)$, support $\left(\mathrm{H}_{23}\right)$ and experience $\left(\mathrm{H}_{24}\right)$ $\mathbf{H}_{3}$ : University students' perceived enjoyment of elearning is effected by presence of entertainment $\left(\mathrm{H}_{31}\right)$ and perceived ease of use $\left(\mathrm{H}_{32}\right)$

$\mathbf{H}_{\mathbf{4}}$ : University students' attitude towards e-learning is effected by perceived usefulness $\left(\mathrm{H}_{41}\right)$, perceived ease of use $\left(\mathrm{H}_{42}\right)$ and perceived enjoyment $\left(\mathrm{H}_{43}\right)$

$\mathbf{H}_{5}$ : University students' behavioral intention to use Elearning is effected by perceived usefulness $\left(\mathrm{H}_{51}\right)$ and attitude towards using E-learning $\left(\mathrm{H}_{52}\right)$

\section{RESEARCH METHODOLOGY}

\section{A. Sample}

The proposed hypotheses were tested by collecting data using a survey method. The population of the study was the university students who follow computing degrees on five publicly administered universities in the Western Province, Sri Lanka. They are University of Kelaniya, University of Colombo, University of Sri Jayawardhanapura, University of Moratuwa and Kotelawala Defence University. Fifty students who were following computing degrees were randomly selected from each university as the sample. The total sample size is 250. Responses were received from 209 students, giving a response rate of around $84 \%(\mathrm{~N}=209)$. Table 1 summarizes the sample demographic information that was collected for the purpose of data analysis.

\section{B. Measurement Development}

Measurement items that were taken for this study were developed based on the literature review and the objectives of the research. Each respondent was asked to fill a questionnaire with 39 items including a 5-point Likert-Type scale with end points being 'strongly disagree' and strongly agree'. A pilot test was performed for a random sample of 20 respondents and the questionnaire was modified based on the results.

\section{DAta ANALYSIS AND RESUlts}

The parametric statistical techniques were used to test the proposed research hypotheses. Factor analysis was performed to examine the construct validity of measures and the Cronbach's alpha was used for the reliability analysis. The correlation analysis was performed to test 
the relationship between the perceived ease of use, perceived usefulness, perceived enjoyment, attitude towards involving e-learning and intention to use elearning. The regression technique is used to examine the statistical significance of the predictors and the dependent variable. Also it showed the strength of independent variables to the dependent variable which were involved in the model. SPSS Statistics 20 was used for the data analysis and interprets the data.

Table 1. Sample Demographic Information

\begin{tabular}{|c|c|c|}
\hline Variables & Characteristics & Percentage \\
\hline \multirow{2}{*}{ Gender } & Male & 47.4 \\
\cline { 2 - 3 } & Female & 52.6 \\
\hline \multirow{3}{*}{$\begin{array}{c}\text { Current year of } \\
\text { university }\end{array}$} & First Year & 32.5 \\
\cline { 2 - 3 } & Second Year & 29.2 \\
\cline { 2 - 3 } & Third Year & 19.6 \\
\cline { 2 - 3 } Experience of & Fourth Year & 18.2 \\
\cline { 2 - 3 } E-Learning & Less than 2 years & 25.8 \\
\cline { 2 - 3 } & 2- 5 Years & 64.3 \\
\cline { 2 - 3 } & 5-10 Years & 9.3 \\
\hline \multirow{3}{*}{$\begin{array}{c}\text { Owner of } \\
\text { Computer }\end{array}$} & More than 10 years & 0.55 \\
\cline { 2 - 3 } & Yes & 93.3 \\
\hline
\end{tabular}

\section{A. Measurement Reliability}

The reliability analysis was conducted to ensure the internal validity and consistency of the questionnaire items used for each variable in the research model.Cronbach Alpha values from .6 to .7 were said to be the lower limit of acceptability [16]. An Alpha of more than .7 would indicate that the items are homogeneous and measuring the same constant [17]. Table 2 shows the reliability of the measurement scales as all the alpha values are over 0.8 , which is considered to be good [17]. So the questionnaire could be taken as a reliable research instrument.

\section{B. Measurement Validity}

Measurement validity was performed in terms of reliability and construct validity. To examine the construct validity of items, the factor analysis was performed. Principal axis factoring analysis with Varimax rotation was conducted to assess the validity of 39 items of the questionnaire. The items were designed to construct 10 factors as mentioned in Table 3. It displays the items and factor loadings for the rotated factors.

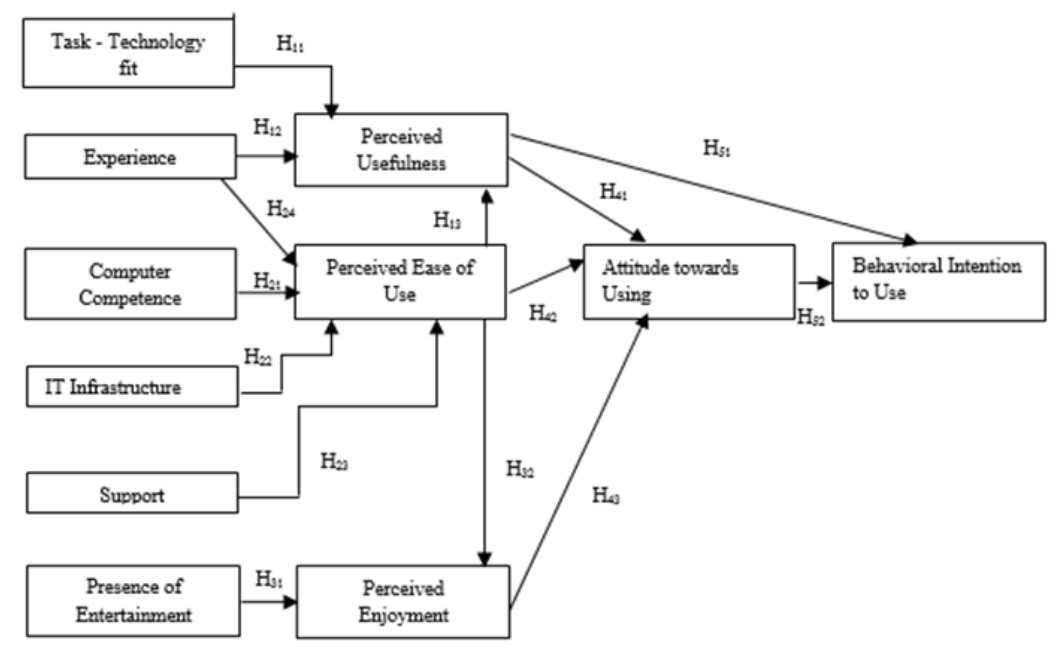

Fig.3. The Research Model

The factor analysis consisted of ten factors based on the minimum Eigen value of one. The Extraction sum of squares produces a cumulative value of $76.7 \%$ in explaining the total variance of data. As the entire factor loadings were above 0.6 , it showed a good convergent validity [18].

\section{Correlation Analysis}

Table 4 shows that the Pearson correlations between U, EU, PE and IU are positive and significant. This confirms the original hypotheses which were derived from the literature based on TAM. As the coefficients are nearby to 1.0 , the relationship is total positive among all the factors.

\section{Hypotheses Testing}

The regression analysis technique was used to test the hypotheses. Hypotheses H11, H12, H13 were tested with perceived usefulness as the dependent variable and tasktechnology fit, experience and perceived ease of use as independent variables. Hypotheses H21, H22, H23,H24 were tested with perceived ease of use as the dependent variable and computer competence, IT infrastructure, support and experience as independent variables. Hypotheses H31, H32 were tested with perceived enjoyment as dependent variable and perceived ease of use and presence of entertainment as independent variables. Hypotheses H41, H42, H43 were tested with attitude towards using E-learning as dependent variable and perceived ease of use, perceived usefulness and perceived enjoyment as independent variables. Hypotheses H51, H52were tested with intention to use as 
dependent variable and perceived usefulness and attitude towards using as independent variables.

Table 2. Cronbach's alpha values

\begin{tabular}{|c|c|}
\hline Scale & Cronbach's Alpha \\
\hline Task-Technology Fit & .819 \\
\hline Computer Self-efficacy & .832 \\
\hline Support & .853 \\
\hline IT Infrastructure & .855 \\
\hline Presence of Enjoyment & .953 \\
\hline Perceived Usefulness & .982 \\
\hline Perceived Ease of Use & .981 \\
\hline Perceived Enjoyment & .980 \\
\hline Attitude & .987 \\
\hline Intention to Use & .992 \\
\hline
\end{tabular}

Table 3. Factor Loadings

\begin{tabular}{|c|c|c|c|}
\hline Factor & Items & $\begin{array}{c}\text { Factor } \\
\text { Loadings }\end{array}$ & $\begin{array}{c}\text { \% variance } \\
\text { explained }\end{array}$ \\
\hline \multirow[t]{3}{*}{$\begin{array}{c}\text { Task- } \\
\text { Technology Fit } \\
\text { (TT) }\end{array}$} & TT5 & .625 & \multirow[t]{3}{*}{21.6} \\
\hline & TT6 & .879 & \\
\hline & TT7 & .749 & \\
\hline \multirow[t]{4}{*}{$\begin{array}{l}\text { Computer } \\
\text { Competence } \\
(\mathrm{CC}) \\
\end{array}$} & $\mathrm{CC} 8$ & .748 & \multirow{4}{*}{10.33} \\
\hline & CC9 & .849 & \\
\hline & $\mathrm{CC} 10$ & .746 & \\
\hline & CC11 & .554 & \\
\hline \multirow[t]{3}{*}{ Support (S) } & $\mathrm{S} 12$ & .845 & \multirow{3}{*}{9.45} \\
\hline & S13 & .766 & \\
\hline & S14 & .855 & \\
\hline \multirow[t]{4}{*}{$\begin{array}{c}\text { IT Infrastructure } \\
\text { (IT) }\end{array}$} & IT15 & .606 & \multirow{4}{*}{8.34} \\
\hline & IT16 & .662 & \\
\hline & IT17 & .836 & \\
\hline & IT18 & .889 & \\
\hline \multirow[t]{3}{*}{$\begin{array}{c}\text { Presence of } \\
\text { Enjoyment (E) }\end{array}$} & E19 & .762 & \multirow{3}{*}{11.89} \\
\hline & E20 & .807 & \\
\hline & E21 & .799 & \\
\hline \multirow[t]{4}{*}{$\begin{array}{c}\text { Perceived } \\
\text { Usefulness (U) }\end{array}$} & $\mathrm{U} 22$ & .805 & \multirow{4}{*}{3.2} \\
\hline & U23 & .827 & \\
\hline & U24 & .854 & \\
\hline & $\mathrm{U} 25$ & .766 & \\
\hline \multirow[t]{4}{*}{$\begin{array}{c}\text { Perceived Ease } \\
\text { of Use(EU) }\end{array}$} & EU26 & .686 & \multirow{4}{*}{2.1} \\
\hline & EU27 & .776 & \\
\hline & EU28 & .734 & \\
\hline & EU29 & .746 & \\
\hline \multirow[t]{3}{*}{$\begin{array}{c}\text { Perceived } \\
\text { Enjoyment }(\mathrm{PE})\end{array}$} & PE30 & .748 & \multirow{3}{*}{4.2} \\
\hline & PE31 & .738 & \\
\hline & PE32 & .766 & \\
\hline \multirow[t]{3}{*}{ Attitude(A) } & A33 & .758 & \multirow{3}{*}{3.2} \\
\hline & A34 & .737 & \\
\hline & A35 & .763 & \\
\hline \multirow[t]{4}{*}{$\begin{array}{c}\text { Intention to } \\
\text { Use(IU) }\end{array}$} & IU36 & .733 & \multirow{4}{*}{2.4} \\
\hline & IU37 & .745 & \\
\hline & IU38 & .666 & \\
\hline & IU39 & .543 & \\
\hline
\end{tabular}

The Table 5 summarizes all the results that were associated with hypotheses. The $\mathrm{R}$ squared value shows that the variation explained in dependent variable due to the independent variables. That explains the coefficient of determination. The value is greater than $75 \%$ for all the five models. According to the results of Table 5, all the factors are statistically significant at 5\% level of significance except the factor experience $(\mathrm{p}>0.05)$. The $\mathrm{p}$ value corresponding to all the other factors are less than 0.05 .

Table 4. Correlation Results

\begin{tabular}{|c|c|c|c|c|c|}
\hline Factor & U & EU & PE & A & IU \\
\hline U & 1 & 0.944 & 0.938 & 0.956 & 0.958 \\
\hline EU & 0.944 & 1 & 0.961 & 0.970 & 0.967 \\
\hline PE & 0.938 & 0.961 & 1 & 0.963 & 0.961 \\
\hline A & 0.956 & 0.970 & 0.963 & 1 & 0.985 \\
\hline IU & 0.958 & 0.967 & 0.961 & 0.985 & 1 \\
\hline
\end{tabular}

Hence, except the hypotheses $\mathrm{H}_{12}$ and $\mathrm{H}_{24}$, all the other hypotheses are accepted. That means the experience on E-learning has no significant effect on usefulness and ease of use at $5 \%$ significance level.

The strength of the predictive factors were determined by the standardized coefficient (Beta) as shown in Table 5. Ease of use has a relatively higher impact for the usefulness than task technology fit. The availability of IT Infrastructure has a relatively higher impact on ease of use than computer competence and support. Also the ease of use has a relatively higher impact for perceived enjoyment than presence of entertainment, while ease of use has a relatively higher impact on attitude towards using E-learning. Also the attitude towards using Elearning has a relatively higher impact for the behavioral intention to use E-learning. Fig. 4 shows the results of the regression analysis.

\section{IMPLICATIONS AND RECCOMENDATIONS}

This study investigated the factors which were effected for the acceptance of E-learning among the university students. Several implications can be drawn from the findings of this study. First, the findings of this study revealed that, in order to increase the university students' intention to use the E-learning, the positive attitude towards using is crucial; whereas the perception of usefulness may not be equally important. Training and information sessions on E-learning need to be primarily focused on students which can help to improve the attitude towards the E-learning process.

Then the students may understand how effectively and efficiently they can use this technology to improve their knowledge level. Also according to the research findings, by improving the IT infrastructure and related technologies the students' can easily adopt with Elearning process and that would make the positive sense over the attitude. So the universities should pay more attention on providing necessary lab equipment, internet facilities, stationeries etc. which would make more easy to use the technology without much effort. So it is a 
Table 5. Regression Results

\begin{tabular}{|c|c|c|c|c|c|c|}
\hline $\begin{array}{l}\text { Dependent } \\
\text { Variable }\end{array}$ & Model & Beta & $\begin{array}{l}\text { Std. } \\
\text { Error }\end{array}$ & t value & $P$ value & $\begin{array}{l}\text { R Squared } \\
\text { Value }\end{array}$ \\
\hline \multirow{4}{*}{$\mathrm{U}$} & (Constant) & & .248 & .154 & .878 & \multirow{4}{*}{.896} \\
\hline & TT & .086 & .063 & 3.444 & .001 & \\
\hline & EU & .912 & .021 & 37.149 & .000 & \\
\hline & Experience & .004 & .038 & .186 & .852 & \\
\hline \multirow{5}{*}{ EU } & (Constant) & & .422 & -7.808 & .000 & \multirow{5}{*}{.758} \\
\hline & $\mathrm{CC}$ & .238 & .108 & 5.675 & .000 & \\
\hline & $\mathrm{S}$ & .370 & .098 & 7.354 & .000 & \\
\hline & IT & .419 & .073 & 8.519 & .000 & \\
\hline & Experience & -.045 & .066 & -1.271 & .205 & \\
\hline \multirow{3}{*}{ PE } & (Constant) & & .151 & -7.141 & .000 & \multirow{3}{*}{.925} \\
\hline & EU & .820 & .051 & 18.576 & .000 & \\
\hline & $\mathrm{E}$ & .155 & .071 & 3.503 & .001 & \\
\hline \multirow{4}{*}{ A } & (Constant) & & .112 & 8.513 & .000 & \multirow{4}{*}{.961} \\
\hline & EU & .424 & .070 & 7.532 & .000 & \\
\hline & PE & .287 & .057 & 5.452 & .000 & \\
\hline & $\mathrm{U}$ & .287 & .065 & 6.441 & .000 & \\
\hline \multirow{3}{*}{ IU } & (Constant) & & .115 & -7.570 & .000 & \multirow{3}{*}{.971} \\
\hline & $\mathrm{A}$ & .197 & .066 & 4.884 & .000 & \\
\hline & $\mathrm{U}$ & .796 & .045 & 19.782 & .000 & \\
\hline
\end{tabular}

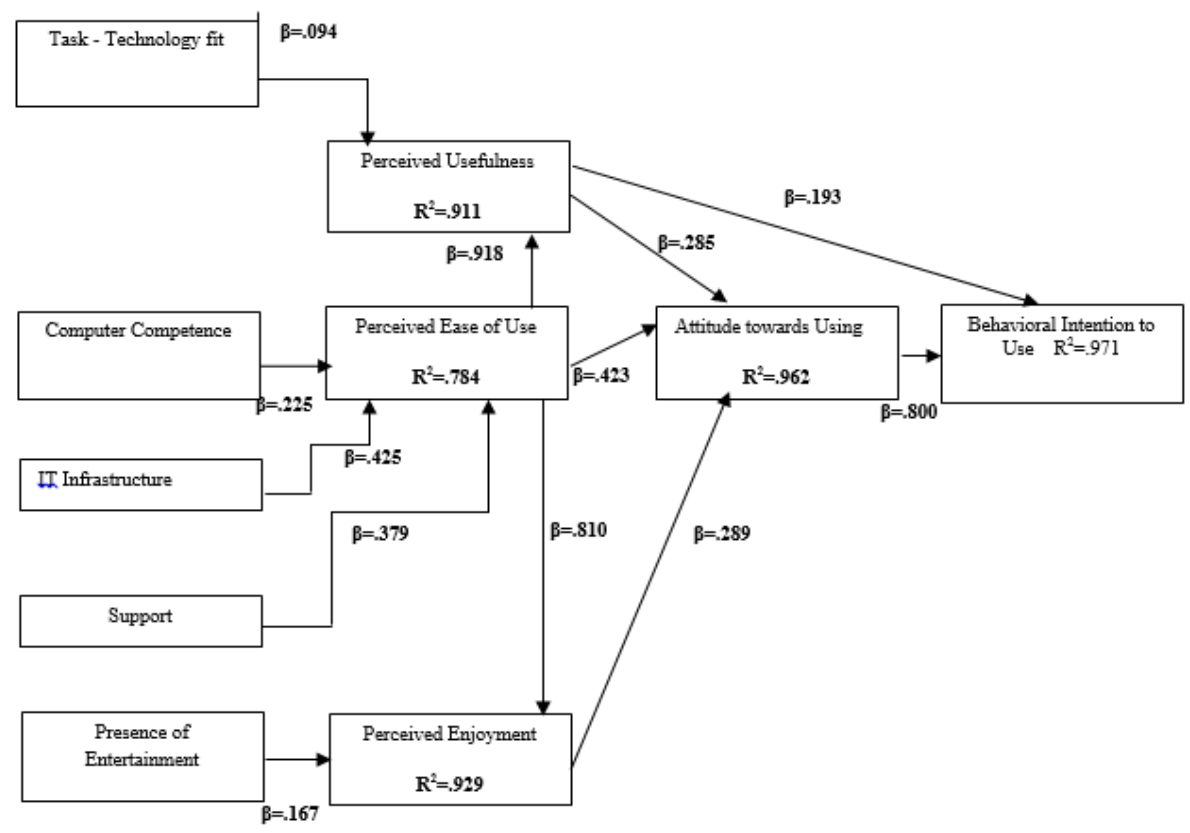

Fig.4. Results of Regression Analysis

noticeable factor that the students' prior experience on Elearning has no effect to the perception of usefulness and ease of use. So the academic staff of the university should pay more attention to improve the other factors of the research model except the prior experience.

\section{LIMITATIONS AND FUTURE DIRECTIONS}

As this study totally focused on the undergraduates who were following computing degrees in Sri Lanka. As all the students have the prior knowledge on computing, it was shown that the experience has no effect to the model itself. Also as this study evaluates the cognitive behavior of the students such as perceive, attitude and behavioral intention, the results coming from the questionnaires were qualitative. Those qualitative results would generate critical results.

While the results of the significant relationship between the predictive factors of TAM may be suitable for E-Learning environment, the model can be extended by including some more predictive factors such as student characteristics, learning area and normative factors. Also the same research model can be used for analyse the student acceptance behavior of E-learning among different undergraduate groups. 


\section{CONCLUSION}

This study was to examine the factors that were effected to the acceptance of E-learning among university students who were following computing degrees. The research model was developed based on the TAM, after including the factors related with the research review. The data was collected from 209 university students who were studying computing degrees in public universities of Western Province in Sri Lanka. The results showed that the experience of using e-learning has no effect to the perceived usefulness and perceived ease of use. All the other factors have a relative importance for the dependent variables. The results suggested that availability of technologies and infrastructure will make the E-learning more ease to use and this will make the positive attitude towards using E-learning among university students. The students were more focused on attitude towards using elearning rather than the beneficiaries they could achieve through E-learning.

The positive attitude makes them more behavioral intention to use E-learning for the university studies. In this context, providing proper technologies and IT infrastructures is essential for directing the university students' towards the acceptance of E-learning.

Finally this research showed that all the suggested factors have somewhat effect except the experience towards using, to the behavioral intention to use Elearning among university students.These kinds of information are more important for academic institutions when there are designing or improving e-learning systems within the institutions. Therefore, it has become essential for academic institutions to identify the factors effecting students intention towards using E-learning.

\section{ACKNOWLEDGMENT}

I would like to thank all the university students in the selected five universities for their kind cooperation on this research. Furthermore, I would like to acknowledge all my colleagues who supported me to collect the responses from the different universities.

\section{REFERENCES}

[1] G. Chadha and N. Kumail, "E-learning: an expression of the knowledge economy", 1993 New Delhi : Tata McGraw-Hill Publishing.

[2] D.S.Priyangika and C.C. Jayasundara, "IT students' perceptions on e-learning: a preliminary survey at University of Colombo", 2012, Journal of the University Librarians Association, Sri Lanka, 16(2), pp.160-178.

[3] S.K. Sharma and J.K. Chandel, "Technology Acceptance Model for the use of learning through websites among students in Oman", 2013, International Arab Journal of $e$ technology, 3(1), pp.44- 49.

[4] F.D.Davis, R.P.Bagozzi and P.R.Warshaw, "User Acceptance of Computer Technology: A Comparison of Two Theoretical Models", 1989, Management Science, 35(8), pp. 982-1003.

[5] H.Van der Heijden, "User Acceptance of Hedonic Information Systems”, 2004, MIS Quarterly,28(4), pp.695704.
[6] V.Venkatesh and H. Bala , "Technology Acceptance Model 3 and a Research Agenda on Interventions",

[7] D.A. Adams, R.R. Nelson and P.A.Todd, "Perceived usefulness, ease of use, and usage of information technology : A replication”,1992 ,MIS Quartely, 16(2),pp.227-247.

[8] F.D.Davis, "Perceived usefulness, perceived ease of use, and user acceptance of information technology", 1989, MIS Quarterly 13 (3), pp.319-340.

[9] I.Ajzen and M.Fishbein, "Understanding attitudes and predicting social behavior", 1980, Englewood Cliffs, NJ: Prentice-Hall.

[10] I. Ajzen, "Perceived Behavioral Control, Self-Efficacy, Locus of Control, and the Theory of Planned Behavior", 2002, Journal of Applied Social Psychology, 32, pp.665683.

[11] M. Masrom, "Technology Acceptance Model and ELearning", 2007, 12 International Conference on Education, ultanHassanalBolkiah Institute of Education, University of Darussalam.

[12] I.Ajzen,"The theory of planned behavior", 1991, Organizational Behavior and Human Decision Processes, 50, pp.179-211.

[13] J.R.Hauser and S.M.Shugan, "Intensity Measures of Consumer Preference", 1980(March-April), Operation Research, Vol. 28, No. 2, pp.278-320.

[14] D.F. Larcker and V.P.Lessig, "Perceived Usefulness of Information: A Psychometric Examination", 1980, Decision Sciences, 11 (1).

[15] A.Dillon and M.G.Morris, "User acceptance of information technology: Theories and models", 1996, Annual Review of Information Science and Technology, 31, pp.3-32.

[16] J.F.Hair, R.E. Anderson, R.L. Tatham and W.C.Black, "Multivariate Data Analysis", 1998, (5th ed.) New Jersey: Prentice-Hall International.

[17] P.Kline, "The handbook of psychological testing", 2000, (2nd ed.), London: Routledge, pp.13.

[18] T. Chesney, "An acceptance model for useful and fun information systems", 2006, Human Technology, 2(2), pp.225-235.

[19] Goodhue, L. Dale,"Development and measurement validity of a task-technology fit instrument for user evaluations of information systems", Decision Sciences, 1998, 29(1),pp.105-138.

[20] T.P.Monsuwe, T. Perea,B.G. Dellaert and K.D.Ruyter ,"What drives consumers to shop online? A literature review", 2004, International Journal of Service Industry Management 15(1), pp. 102-121.

[21] S.M.Song,'E-learning: Investigating students' acceptance of online lerning in hospitality programs", 2010, Graduate Theses and Dessertations. Paper 11902

[22] B.C.Lee, J.O.Yoon and I.Lee, "Learners' acceptance of elearning in South Korea: Theories and results", 2009, Computers \& Education.pp.1320-1329

[23] B.L.C.Yiong,H.K.Sam and T.K.Wah,"Acceptance of e learning among distance learners: A Malaysian perspective",2008, Proceedings ascilite Melbourne

[24] C.P.H.Ernst,K.Wedel and F.Rothlauf , "Students' Acceptance of E-Learning Technologies: Combining the Technology Acceptance Model with the Didactic Circle",2014. Twentieth Americas Conference on Information Systems, Savannah. 


\section{Authors' Profiles}

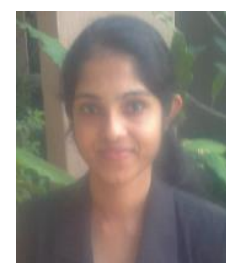

Dushyanthi U. Vidanagama received her BSc. (Special) (Hons) in Statistics and Computer Science in University of Kelaniya , Sri Lanka in 2009 and MSc. in Management and Information Technology in University of Kelaniya, Sri Lanka in 2015 .

Now she is reading for $\mathrm{PhD}$ from University of Moratuwa, Sri Lanka. She is currently teaching in
Department of IT in General Sir John Kotelawala Defence University, Sri Lanka. Her research interests include E-Learning, Data Mining and XML Databases.

How to cite this paper: Dushyanthi U. Vidanagama,"Acceptance of E-Learning among Undergraduates of Computing Degrees in Sri Lanka", International Journal of Modern Education and Computer Science(IJMECS), Vol.8, No.4, pp.25-32, 2016.DOI: 10.5815/ijmecs.2016.04.04 